\title{
Management of Katishool by Shaman aushadhi along with Panchkarma therapy A case study
}

\section{Case Report}

\author{
Chudasama Hardik $\mathbf{Y}^{1}$, Yadav $\mathbf{C R}^{2}$, Pareek Pooja ${ }^{3}$ \\ 1. PG Scholar, PG Department of Sharir Kriya, NIA, Jaipur. \\ 2. Associate Professor, PG Department of Sharir Kriya, NIA, Jaipur. \\ 3 MD Scholar, PG Department of Sharir Kriya, NIA, Jaipur.
}

\begin{abstract}
Spondylosis refers to degenerative changes in the spine such as bone spurs and degenerative changes in intervertebral disc. Lumber spondylosis mainly affects on lower spine. In this condition spine is compromised by a narrowing of the space between the vertebrae. In a classic case of lumber spondylosis, the space between discs in the lumbar spine becomes narrowed. Because of this the patient develops numbness, tingling and pain which seem to radiate out from the area. These symptoms are the results of pressure on the nerves as they exit the spinal cord. It has been estimated that about $80 \%$ of world population develop lumber spondylosis after the age of 40 years. In Ayurveda, It can compare with a disease Katishool, characterized by Kati pradeshevedana, Kati shunyata, kriya hani, Hasta-pada suptata.in this article we are focusing in the management of Lumber spondolosis (Katishool) through Ayurveda. A 46 year old male patient reported to the outdoor department of Sharir Kriya NIA, Jaipur, with the complains of Kati pradeshevedana (Pain in Lumber region), Kati shunyata (Numbness), Dourbalyata (Weakness), Shramahani (Lethargy) for last 6 month and other associate complaints were Hypertension, debility, lethargy, excessive sleep, burning micturation for four month. The patient was diagnosed as Lumber spondylosis. A combination of Yogaraj Guggulu (2 Tab), Punarnavadi Guggulu (2 Tab) twice a day, along with Dashmoolkwath (40 ml), Capsule Sandhika (1 tab), Grokart Ds (2 Tab), Chropexae (1 Tab) twice a day with water after meal for one months. Patient is treated with some panchkarma procedure like katibasti and karma basti. After one month of treatment a significant response was found.
\end{abstract}

Keywords: Lumber spondylosis, Katishool, Shaman Aushadhis, Shansodhan Aushadhis.

\section{Introduction}

Spondylosis generally initiates from the inter-vertebral disc. At this level progressive biochemical and structural changes take place leading to a modification in the physical properties of elasticity and mechanical resistance. Disc lesions cause pathological changes in the vertebral bodies, where osteophytes appear (1). Lumber Spondylosis is asymptomatic disease but in MRI L.S. Spine study, there is significant in bulge of L3 \& L4-5 discs mild ligamentum flavum thickening and early facet arthopathy (2).

Approximately $28 \%$ of patients had spinal disorders; although low back pain is a common condition that affects as many as $80-90 \%$ of people during their life time. It is more common between 30 to 50 years of age (3).

According to Ayurveda it can be co- related

\section{*Corresponding Author:}

\section{Chudasama Hardik}

PG Scholar,

PG Department of Sharir Kriya,

NIA, Jaipur

Email-chudasamahardik1991@gmail.com to the disease katishool which manifests in the form of Kati pradeshevedana, Kati shunyata, kriya hani, Hasta-padasuptata (4).

The Ayurvedic therapies for spondylosis may not completely reverse the degenerative changes, the Vatahara, Shothnashak and Vednahar medicines and massage oil helps to reduce pain. The excessive use of oils helps in the pacification of Vata, it tones, strengthens the muscle supporting spinal joint (5).

\section{Aims and Objectives}

To estimate the efficacy of Ayurveda therapies in management of Katishool W.S.R. Lumbar-spondylosis.

\section{Materials and Methods}

Types of Study- Single observational case without any control group.

Study center- National Institute of Ayurveda Hospital, Jaipur (Rajasthan)

\section{Case Report}

A Hindu, married 46 year old male patient visited (May 10, 2017) the outdoor department of 
Sharir Kriya of NIA, Jaipur with OPD no 11110052017 for the chief complains of Pain in legs, Difficulty in sitting and standing, Dourbalyata, Shramahani, Numbness of legs for last 6 months, and other associated complains were Mutra-daah (Burning micturation), Uchcharaktach-ap (High blood pressure), atinidra(excessive sleep) for last 4 month.

Personal history revealed that the patient take mixed (Veg/Non-Veg) type of diet and used to take extra oily and fatty diet, with irregular habit of intake. Amount of urine is 5-6 times/day with burning micturation.

\section{Past history}

There is no any significant past history.

\section{Family history}

There is no any significant family history.

The General examination of the patients showed swelling and pain in legs and vitals being pulse rate $80 / \mathrm{min}$, respiratory rate of $20 / \mathrm{min}$, blood pressure of $140 / 80 \mathrm{~mm}$ of $\mathrm{Hg}$ and body weight is $80 \mathrm{~kg}$. S.L.R.(Straight Leg Raising )test positive in right leg with 45 degree and tremors in neck region. In hematology examination E.S.R. is $37 \mathrm{~mm} / \mathrm{hr}$. In urine examination $\mathrm{ph}$ is 5.5 epithelial cells 5-6, W.B.C. is 4-5 and calcium oxalate also present. The impression of M.R.I. on April 29, 2017 implies broad based posterocentral / right paracentral disc herniation / extrusion ( $5 \mathrm{~mm}$ caudal migration) with annular fissuring at L 4-L5 level impinging of thecal sac and causing moderate narrowing of bilateral lateral spinal recess and abutting bilateral traversing nerve roots $(\mathrm{R}>\mathrm{L})$. Moderate - severe central canal stenosis. Bilateral facet joint arthropathy. Based on clinical presentation, Patient was diagnosed as a case of katishool.

\section{Symptoms}

Pain and stiffness in back region, radiating pain, and numbness $\&$ tingling sensation in lower limb difficulty in walking and sitting and changing the posture since 6 months.

\section{General Examination - \\ - Prakriti-Vata kapha \\ - Vaya-Madhyam \\ - Bala-Madhyam \\ - Agni-Madhyam \\ - Koshtha-Madhyam \\ - Gait- slow (With support)}

The Following oral medicines were administrated for 2 month.

- A combination of Yograj guggulu (2 tab), Punarnavadi gugglu (2 tab) are administrated with Dashmool kwath $(40-40 \mathrm{ml})$ twice a day before Meal.

- Cap.Sandhika (1-1 tab) and tab.Grokart DS(22 tab) twice a day with water are administrated after Meal.

- Triphala Churna (5g) is administrated orally at night with Luke warm water.

Along with oral medication Panchkarma treatment katibasti with Mahavishgarbh tail and Brihat Saindhvaditail and karma basti with Kshirbala tail $(50 \mathrm{ml})$ anuvasana basti and Niruha basti $(300 \mathrm{ml})$ with Erandamoolaadi yapana basti.

\section{Kati basti (6)}

The procedure of applying heat to the sacral or lumber region by retaining warm medicated oil with in a specially formed frame on this area is known as kati basti. It is indicated in painful condition of lower back region. The procedure was done with Maha vishgarbha taila and brihat saindhvadi taila for 30 minutes for duration of 15 -15 days two seating twice a day.

\section{Basti Karma-}

\section{Niruha basti (7)}

The composition of the medicine administrated in the form of Basti contains Kwath (herbal decoction), Sneha (Medicated oil), Madhu (Honey), Saindhava Lavana (rock salt) and Kalka (Herbal powder).

Erandmooladi Niruh basti was given in kala basti schedule (16 days) with the following contents.

- Madhu- $60 \mathrm{gm}$

- Saindhav lavana - 5 gm

- Goghrit - $50 \mathrm{ml}$

- Shatpushpa kalka - $30 \mathrm{gm}$

- Erand mooladi kwath - $200 \mathrm{ml}$ The contents of kwath are Erandmoola, palasha, Laghupanchmoola, Rasna, Ashwagandha, Atibala, Guduchi, Punarnava, Aragvadha, Devdaru, madanphala.

\section{Anuvasan basti (8)}

Administration of Medicated oil or other sneha drvya through the rectal route in prescribe dose is called as Anuvasana basti. In this case study Kshirbala taila was used for Anuvasana basti.

\section{Observation}

- Subjective criteria- Pain, Paresthesia, Stiffness, posture

- Objective Criteria- Walking time, Walking distance, SLR, MRI Findings 
Table-1 (Before treatment)

\begin{tabular}{|c|c|c|c|}
\hline $\begin{array}{l}\text { Subjective } \\
\text { criteria }\end{array}$ & Gradation & $\begin{array}{l}\text { Objective } \\
\text { Criteria }\end{array}$ & Gradation \\
\hline Pain & 3 & $\begin{array}{l}\text { Walking } \\
\text { time }\end{array}$ & $\begin{array}{lr}\text { Took } & \\
\text { around } 5 & -7 \\
\text { minutes to } \\
\text { walk } 100 \\
\text { steps } \\
\end{array}$ \\
\hline Paresthesia & $\begin{array}{l}3 \text { (Serious } \\
\text { problem) }\end{array}$ & $\begin{array}{l}\text { Walking } \\
\text { distance }\end{array}$ & $\begin{array}{l}\text { Severe pain } \\
\text { after } \\
\text { walking } 100 \\
\text { meters }\end{array}$ \\
\hline Stiffness & $\begin{array}{l}3 \text { (A great } \\
\text { deal) }\end{array}$ & SLR & $\begin{array}{lr}\text { Positive } & \text { in } \\
\text { right } & \text { leg } \\
\text { with } & 45 \\
\text { degree } & \end{array}$ \\
\hline Posture & $\begin{array}{l}\text { Difficulty in } \\
\text { changing } \\
\text { the posture }\end{array}$ & $\begin{array}{l}\text { MRI } \\
\text { findings }\end{array}$ & $\begin{array}{l}\text { Postero- } \\
\text { central } \\
\text { right } \\
\text { paracentral } \\
\text { disc } \\
\text { herniation/ } \\
\text { extrusion } \\
\text { (5mm } \\
\text { caudal } \\
\text { migration) } \\
\text { with annular } \\
\text { fissuring at } \\
\text { L 4-L5 level } \\
\text { impinging } \\
\text { of thecal sac }\end{array}$ \\
\hline
\end{tabular}

\section{Results -}

Table - 2 (After treatment)

\begin{tabular}{|l|l|l|l|}
\hline $\begin{array}{l}\text { Subjective } \\
\text { criteria }\end{array}$ & Gradation & $\begin{array}{l}\text { Objective } \\
\text { Criteria }\end{array}$ & Gradation \\
\hline Pain & 1 & $\begin{array}{l}\text { Walking } \\
\text { time }\end{array}$ & $\begin{array}{l}\text { Took three } \\
\text { minute to } \\
\text { walk100 } \\
\text { steps }\end{array}$ \\
\hline Paresthesia & $\begin{array}{l}1 \quad \text { (minor } \\
\text { problem) }\end{array}$ & $\begin{array}{l}\text { Walking } \\
\text { distance }\end{array}$ & $\begin{array}{l}\text { Walk } \\
\text { without } \\
\text { pain about } \\
500 \text { m }\end{array}$ \\
\hline Stiffness & 1 & SLR & $\begin{array}{l}\text { Negative } \\
\text { Posture }\end{array}$ \\
$\begin{array}{l}\text { Markedly } \\
\text { improved }\end{array}$ & $\begin{array}{l}\text { MRI } \\
\text { findings }\end{array}$ & $\begin{array}{l}\text { No } \\
\text { significant } \\
\text { changes }\end{array}$ \\
\hline
\end{tabular}

Table 3: Pattern of grading

\begin{tabular}{|l|l|}
\hline Score & Interpretation \\
\hline 3 & No change \\
\hline 2 & Mild Improved \\
\hline 1 & Moderate/markedly improved \\
\hline 0 & Complete improved \\
\hline
\end{tabular}

\section{Discussion}

Acharya Charaka describes each and every pain is just because of aggravated or vitiated Vata dosha. To treat this condition Vatashaman dravya and procedures are choice of treatment protocol to treat vitiated Vata dosha. Here in this case shaman drugs as well as some Panchkarma procedures are also used to treat the disease (9).

\section{1) Shamana yoga}

Mainly Amapachaka, sothahara, brimhaniya and vatahara drugs are choice of drug to treat the katishoola. It might have helped to overcome degeneration of disc and vata prakopa.

\section{2) Kati basti}

It is a combination of snehana and swedana procedure which help to subside the aggravated Vata dosha. Maha vishgarbha taila and brihat saindhvadi taila have vata-kapha shamak properties and by nature snehana dravyas help to overcome the accumulation of vata at the site of lumbar region and may nourish the underlying tissue.

\section{3) Basti}

As per acharya charak 'Bastivataharanam' it means basti is best treatment for vata dosha (10). Further Erandmooladi yapan basti was specially selected for their indication in the treatment of Jangha, uru, pada, prushtha, shoola. Combination of drugs in Erandmooladi basti, it works on avaranjanya vata dosha and induced free movement of vata dosha which may be reason for reduction in pain, numbness and improvement of gati. Basti and tikta rasa predominance drugs should be given in A shthipradoshaj vicar (11).

Go-ghrita and ksheer bala taila used as a sneha in basti is specifically mentioned as rasayan which helps to corrects the degenerative changes that took place at the level of lumber disc by its snigdha guna, balya and brimhaniya action (12).

\section{Conclusion}

On the basis of this single case study it can 
be concluded that Samshaman aushadhis and Panchkarma procedures like Kati basti, Erandmooladi nirha basti had been effective in the management of katishoola (Lumber spondolysis).

\section{Financial support and sponsership Nil}

\section{Conflict of Interest}

There are no conflicts of interest.

\section{References}

1. Middleton, Kimberely, and David E. Fish. "Lumber Spondolysis: Clinical Presentation and treatment Approches" Current review in Musculoskeletal Medicine 2, no 2 (March 25, 2009): 94-104

2. Zukowski et al. the influence of Sex, age and BMI on the degeneration of the Lumber spine, Pubmed, 4 Nov 2011

3. Cherubino P. et al, Spondolysys and Lumber instability : Pathogenic changes Chir organi Mov. 1994 Jan-Mar; 79(1) 11-8.

4. Agnivesh; Caraka Samhita, Ayurveda Depika Commentry by Sri Chakrapanidutta, Pt. Yadavji Trikamji Acharya editor,Chaukhamba Prakashan, Varanasi, Reprint 2007, Chikitsasthana Chapter 28/ 56 Page No 619.

5. Agnivesh; Caraka Samhita, Ayurveda Depika Commentry by Sri Chakrapanidutta, Pt. Yadavji Trikamji Acharya editor,Chaukhamba Prakashan , Varanasi, Reprint 2007, Chikitsasthana Chapter 28/ 75-76 Page 620.

6. Agnivesh; Caraka Samhita, Ayurveda Depika
Commentry by Sri Chakrapanidutta, Pt. Yadavji Trikamji Acharya editor, Chaukhamba Prakashan , Varanasi, Reprint 2007, Sutrasthana 14/41-44 Page No 90.

7. Agnivesh; Caraka Samhita, Ayurveda Depika Commentry by Sri Chakrapanidutta, Pt. Yadavji Trikamji Acharya editor, Chaukhamba Prakashan , Varanasi, Reprint 2007, Siddhisthan 3/23 Page No 693.

8. Vagbhat, Ashtanga Hridaya, Sarvangasudara and Ayurveda Rasayan Commentary of Arundutta and Hemadri, Bhisagacharya Pt. Hari Sadashiva shastri Paradakara, Chaukhamba Surbharati Prakashan, Varanasi, 2016, Kalpasiddhisthana Chapter 22/8, Page no 299.

9. Agnivesh; Caraka Samhita, Ayurveda Depika Commentry by Sri Chakrapanidutta, Pt. Yadavji Trikamji Acharya editor, Chaukhamba Prakashan , Varanasi, Reprint 2007, Siddhisthan 1/29-31 Page No 682.

10.Agnivesh; Caraka Samhita, Ayurveda Depika Commentry by Sri Chakrapanidutta, Pt. Yadavji Trikamji Acharya editor, Chaukhamba Prakashan , Varanasi, Reprint 2007, Sutrasthana 25/40, Page 131.

11.Agnivesh; Caraka Samhita, Ayurveda Depika Commentry by Sri Chakrapanidutta, Pt. Yadavji Trikamji Acharya editor,Chaukhamba Prakashan , Varanasi, Reprint 2007, Sutrasthana 28/27, Page 180.

12.Agnivesh; Caraka Samhita, Ayurveda Depika Commentry by Sri Chakrapanidutta, Pt. Yadavji Trikamji Acharya editor, Chaukhamba Prakashan , Varanasi, Reprint 2007, Sutrasthana 27/217-218, Page 165. 